\title{
IDENTIFIKASI KEGIATAN PENANGKAPAN IKAN DI DESA BATILAP, KECAMATAN DUSUN HILIR, KABUPATEN BARITO SELATAN
}

\author{
Rismutia Hayu Deswati \\ Balai Besar Penelitian Sosial Ekonomi Kelautan dan Perikanan \\ JI. KS. Tubun Petamburan VI Jakarta 10260 \\ Telp. (021) 53650162, Fax. (021)53650159 \\ e-mail: rismutia.hd@gmail.com \\ Diterima 12 Maret 2013- Disetujui 25 Mei 2013
}

\begin{abstract}
ABSTRAK
Sungai Barito merupakan salah satu tipologi perairan umum daratan di Indonesia yang memiliki sumber daya ikan berlimpah. Daerah Aliran Sungai Barito bagian tengah mempunyai produksi perikanan yang tinggi dengan jenis keragaman yang banyak, dimana bagian tengah tersebut melewati provinsi Kalimantan Tengah dan Kalimantan Selatan. Desa Batilap di Kabupaten Barito Selatan, Kalimantan Tengah merupakan salah satu daerah yang dilalui oleh aliran Sungai Barito dan anak sungainya. Tulisan ini bertujuan untuk memaparkan hasil identifikasi kegiatan perikanan tangkap yang dilakukan oleh nelayan Desa Batilap di Sungai Barito. Pengumpulan data dilakukan dengan cara survei dan wawancara dengan nelayan yang bersangkutan. Kegiatan perikanan tangkap yang dilakukan nelayan Desa Batilap menggunakan berbagai jenis alat tangkap namun mayoritas yang digunakan adalah selambau, rengge, tempirai dan bubu. Jenis ikan yang diperoleh dari masing-masing alat tangkap yaitu selambau sebanyak 8 jenis, rengge 6 jenis, tempirai 5 jenis dan bubu sebanyak 3 jenis.
\end{abstract}

Kata kunci: alat tangkap, hasil tangkapan, Sungai Barito

Abstract : Identification of Capture Fisheries Activities in Batilap Village, Dusun Hilir District, Barito Selatan Regency. By Rismutia Hayu Deswati.

Barito River is one common typology inland waters in Indonesia, which has abundant fish resources. Barito Watershed middle part has high fisheries production with many types of diversity, which passes through the central part of the province of Central Kalimantan and South Kalimantan. Batilap village in South Barito, Central Kalimantan is one of the areas traversed by the flow of the Barito River and its tributaries. This paper aims to present the result of the identification of fishing activities undertaken by Batilap fishing village on the Barito River. Data was collected by means of surveys and interviews with fishermen concerned. Fishing activities undertaken Batilap village fishermen using various types of fishing gear used, but the majority are selambau, gillnets, and traps tempirai. Types of fish obtained from each gear is selambau by 8 species, 6 species of gillnets, tempirai 5 species and bubu is 3 species.

Keywords : fish gears, catch, Barito River

\section{PENDAHULUAN}

Perairan umum daratan di Indonesia terdiri dari 5 tipologi yaitu danau, lebak, waduk, sungai dan rawa. Setiap tipologi tersebut memiliki karakteristik berbeda dan memiliki berbagai jenis ikan yang tersebar di seluruh Indonesia. Provinsi Kalimantan Tengah adalah salah satu provinsi yang memiliki potensi perairan umum sangat luas, tercatat sebesar 2.290 ha untuk luas perairan danau, rawa sebesar 1.811 .500 ha dan sungai sebesar 323.00 ha yang terdiri dari 11 sungai besar dengan ribuan anak sungai (DKP Kalimantan Tengah, 2010). Sungai Barito merupakan salah satu tipologi perairan umum daratan di Kalimantan Tengah yang memiliki sumber daya ikan yang melimpah.

Zonasi perairan sungai dibagi menjadi 2 bagian besar yaitu perairan bagian retron (hulu) dan potramon (hilir) (Welcome,1985). Sedangkan menurut Utomo (1996) zona perairan sungai dibagi menjadi 3 yaitu perairan daerah aliran sungai bagian hulu, tengah dan hilir. Sungai Barito adalah salah satu sungai besar di Pulau Kalimantan yang bagian hulunya masuk daerah Serawak (Malaysia), bagian tengahnya berada di Kalimantan Tengah dan Kalimantan Selatan serta bagian hilirnya bermuara di Laut Jawa. Menurut Prasetyo dan Asyari (2003) DAS Barito bagian tengah mempunyai produksi perikanan yang tinggi dengan keragaman jenis ikan yang banyak. Aliran Sungai Barito bagian tengah melewati banyak wilayah di Provinsi Kalimantan Tengah dan Kalimantan Selatan yang salah satunya melewati Kabupaten Barito Selatan, Kalimantan Tengah. Oleh karena itu nelayan merupakan mata pencaharian mayoritas penduduknya.

Pada tabel 1 digambarkan bahwa potensi perikanan tangkap dan budidaya perairan umum di Barito Selatan semakin meningkat setiap tahunnya, dimana potensi terbesar dari perairan tangkap di perairan umum Sungai Barito dan sekitarnya yaitu Kecamatan Dusun Selatan dan Kecamatan Dusun Hilir. Di 
dua kecamatan tersebut terdapat beberapa desa yang hampir $100 \%$ penduduknya berprofesi sebagai nelayan tangkap di Sungai Barito dan sungai-sungai sekitarnya. Desa Batilap, Kecamatan Dusun Hilir adalah salah satu desa nelayan di Kabupaten Barito Selatan dengan total kepala keluarga yang berjumlah 400 orang dan semua berprofesi sebagai nelayan tangkap. Daerah tangkapan para nelayan tidak berjarak jauh dari lokasi tempat tinggal yaitu di Simpang Tiga dan Sungai Karamen yang masih bagian aliran dari Sungai Barito.

Menurut Welcome (1985) jenis ikan yang didapatkan di suatu perairan umum daratan dapat digolongkan menjadi 2, yaitu ikan dari habitas asli di sungai yang disebut dengan golongan ikan putih (white fish) seperti ikan patin, baung, jelawat dan berbagai jenis lainnya sedangkan ikan dari habitat rawa lebak disebut dengan golongan ikan hitam (black fish) seperti ikan gabus, sepat, betok dan sebagainya. Namun, dari sekian banyak jenis ikan yang menghuni perairan umum tidak semuanya dapat memberikan keuntungan yang tinggi jika dibudidayakan atau untuk konsumsi pangan (Cahyono,2001). Oleh karena itu nelayan di Sungai Barito pun juga melakukan pemilihan pada jenis ikan yang tertangkap. Jenis ikan yang banyak didapat oleh nelayan tangkap Desa Batilap terdiri atas berbagai jenis yaitu ikan gabus (Channa striata), toman (Channa micropeltes), sepat (Tricogaster pectoralis) dan mujair (Oreochromis mossambicuss).

Menurut Ondara (1992) kegiatan penangkapan ikan di perairan rawa banjiran (floodplain) sangat khas yaitu dengan menggunakan berbagai macam alat yang disesuaikan dengan macam-macam kondisi perairan, tempat dan jenis ikan atau dengan kata lain alat dan cara penangkapan ikan disesuaikan dengan tempat penangkapan dan gerak ruaya ikan yang dipengaruhi oleh perubahan tinggi air. Welcomme (1985) mengelompokkan jenis alat tangkap menjadi alat tangkap pasif dan alat tangkap aktif. Alat tangkap pasif adalah alat tangkap ikan yang tidak digerakkan dalam pengoperasiannya. Alat tangkap jenis ini meliputi: jaring insang, bubu, jebakan dan long line. Alat tangkap aktif adalah alat tangkap ikan yang harus aktif digerakkan pada saat akan dioperasikan. Alat tangkap jenis ini meliputi: jaring lempar, serok, anco, jaring lingkar (purse seine). Nelayan Desa Batilap juga memiliki berbagai jenis alat tangkap yang digunakan sesuai waktu dan jenis ikan yang akan ditangkap. Alat tangkap yang digunakan diantaranya tampirai, rawai, rengge,bubu dan selambau.

Tujuan dari tulisan ini untuk membahas kegiatan perikanan tangkap yang meliputi jenis alat tangkap dan operasionalnya, komposisi hasil tangkapan dan musim tangkap di Desa Batilap, Kecamatan Dusun Hilir, Kabupaten Barito Selatan, Kalimantan Tengah.

\section{METODOLOGI}

Penelitian dilakukan dengan metode survei di sepanjang sisi Sungai Barito dan anak sungainya yang biasa menjadi lokasi penangkapan nelayan. Pengamatan jenis alat tangkap dilakukan dengan mencatat semua alat tangkap yang digunakan nelayan untuk menangkap (Prasetyo, 2006). Lokasi penelitian di Desa Batilap dan Sungai Barito.

\section{AKTIVITAS PERIKANAN TANGKAP NELAYAN BATILAP}

Aktivitas perikanan tangkap yang dilakukan nelayan Desa Batilap di Sungai Barito dan sekitarnya menggunakan berbagai jenis alat tangkap dengan cara pengoperasian yang berbeda-beda (Masterplan Minapolitan Barito Selatan,2012). Setiap nelayan memiliki lebih dari satu jenis alat tangkap dan jumlah minimal 2 unit untuk setiap jenisnya.

\section{Penangkapan dengan Selambau (Seine Net)}

Selambau sebenarnya adalah istilah untuk salah satu teknik penangkapan yang kini sedang populer digunakan oleh para nelayan di Kabupaten Barito Selatan termasuk nelayan Desa Batilap. Memaksa ikan untuk memasuki daerah alat penangkap dan menghadang arus pada arah kiri dan kanan, penghadang makin lama makin menyempit sehingga arus mencapai suatu kecepatan yang tidak mampu lagi dilawan oleh ikan. Dengan demikian ikan masuk kedalam alat penangkap.

Tabel 1. Produksi Perikanan Perairan Umum Daratan (Ton) Menurut Kecamatan di Kabupaten Barito Selatan Tahun 2011.

\begin{tabular}{|c|c|c|c|c|}
\hline \multirow{2}{*}{ No. } & \multirow{2}{*}{ Kecamatan } & \multicolumn{2}{|c|}{ Perikanan Darat } & \multirow{2}{*}{ Jumlah } \\
\hline & & Perikanan Tangkap & Budidaya & \\
\hline 1. & Jenamas & 637,41 & 193,44 & 830,85 \\
\hline 2. & Dusun hilir & $1.231,90$ & 342,74 & $1.574,64$ \\
\hline 3. & Karau kuala & $1.238,86$ & 329,68 & $31.568,54$ \\
\hline 4. & Dusun selatan & 1.476 .43 & $1.330,10$ & $2.806,53$ \\
\hline 5. & Dusun utara & 725,37 & 211,12 & 936,49 \\
\hline \multirow[t]{2}{*}{6.} & G. Bintang awai & 417,28 & 140,30 & 557,98 \\
\hline & Jumlah & $5.727,25$ & $2.547,38$ & $8.274,63$ \\
\hline
\end{tabular}

Sumber : BPS Kabupaten Barito Selatan,2012 
Alat tangkap yang dipasang berupa jaring di sisi-sisi selambau dengan panjang yang berbeda berdasarkan panjang dari selambau itu sendiri. Ikan yang biasa tertangkap adalah ikan gabus, sepat, kakapar dan biawan dengan ukuran yang besar. Sedangkan untuk anak-anak ikan yang tertangkap dilepaskan kembali untuk dipelihara di dalam selambau tersebut. Ikan yang sudah terjebak dan tertangkap kemudian diambil dengan menggunakan serok. Hampir $85 \%$ nelayan Desa Batilap memiliki selambaunya masingmasing dengan ukuran yang tidak sama tergantung kemampuan biayanya karena untuk membuat selambau baru cukup mahal bisa mencapai Rp 3.000.000.

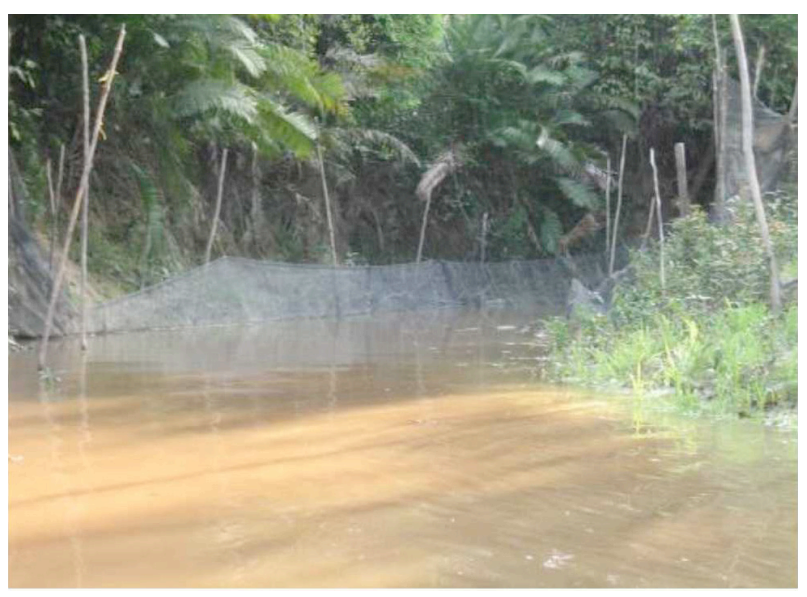

Gambar 1. Penangkapan Dengan Selambau.

\section{Penangkapan dengan Tempirai (Fish Trap)}

Tempirai adalah salah satu alat tangkap yang digunakan oleh nelayan Barito Selatan. Alat tangkap ini terbuat dari bilah rotan yang dianyam berberntuk setengah lingkaran dan menyerupai keranjang (Gambar 2). Ukuran dari alat tangkap ini biasanya $60 \mathrm{~cm} \times 60$ $\mathrm{cm} \times 60 \mathrm{~cm}$ dimana pada salah satu sisinya terdapat pintu masuk. Di pintu masuk tersebut terdapat simpul untuk menahan ikan keluar dengan jarak celah antar bilah $2 \mathrm{~cm}$. Pemasangan alat dilakukan dengan menambatkan pada patok yang dipasang di perairan rawa sedalam $2 / 3$ tinggi dengan umpan yang biasa dipasang adalah buah kelapa. Ikan yang masuk akan terperangkap oleh tempirai yang ada kemudian ikanikan hasil tangkapan tersebut dikeluarkan dengan cara diangkat dan dibuka celah yang ada lalu ikan diambil dengan menggunakan serok yang besar. Tempirai biasa dipasang pada pagi hari kemudian diangkat pada sore hari. Ikan yang biasa tertangkap dengan pengilar adalah ikan gabus dan sepat siam yang berukuran sedang. Setiap nelayan di Desa Batilap memiliki rata-rata 50 buah tempirai yang dipasang secara bergantian.

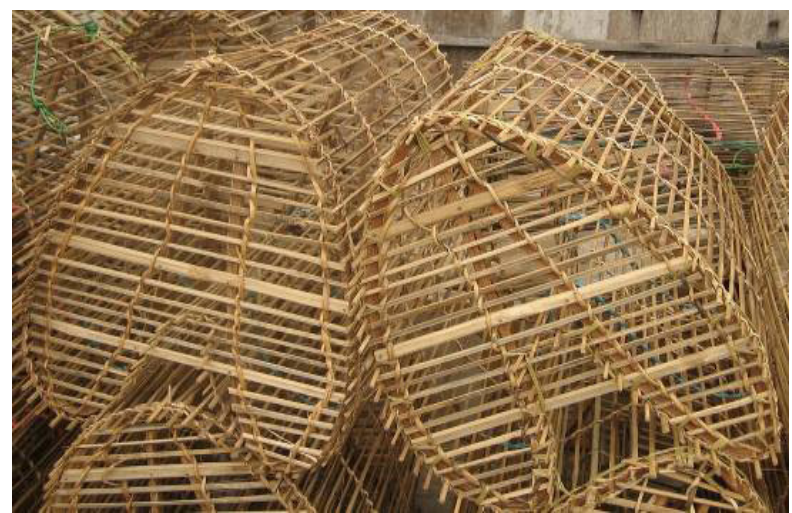

Gambar 2. Alat tangkap Tempirai.

\section{Penangkapan Ikan dengan Rengge (Gill Net)}

Rengge terbuat dari rangkaian benang ataupun nilon yang dianyam dengan menggunakan mesin yang lebarnya 1,5 - $2 \mathrm{~m}$, ukuran mata jaringnya sebesar $1,5-2,5 \mathrm{~cm}$ dan panjangnya $10-12 \mathrm{~m}$ dimana pada bagian atas alat ini dipasang pengapung sedangkan bagian bawahnya dipasang pemberat (Gambar 3). Cara pengoperasionalan rengge yaitu dengan memasang sepanjang anak-anak sungai atau melintang membelah anak sungai yang bagian bawahnya ditenggelamkan mencapai $1,5 \mathrm{~m}$. Alat ini termasuk alat tangkap aktif karena menjebak ikan-ikan yang insangnya masuk ke alat ini biasa dipasang pada pagi hari kemudian diambil hasilnya pada sore hari. Pengambilan hasil tangkapan dilakukan dengan mengangkat rengge dan mengambil ikannya satu per satu.

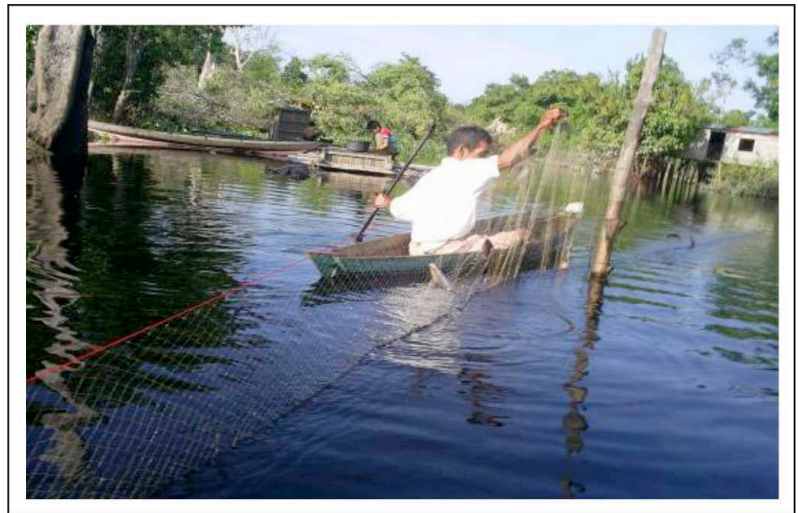

Gambar 3. Penangkapan Ikan dengan Rengge (Jaring Insang).

\section{Penangkapan Ikan Dengan Bubu (Portable Traps)}

Bubu adalah salah satu alat tangkap yang mayoritas digunakan di Kabupaten Barito Selatan. Alat tangkap ini terbuat dari anyaman bambu berbentuk bulat memanjang dengan diameter 10-15 cm, panjang 1,5-2 $\mathrm{m}$ dan celah antar bilah bambu $1 \mathrm{~cm}$ (Gambar 4). Di bagian pangkal terdapat celah untuk masuknya ikan yang dipasang simpul agar ikan yang masuk tidak bisa keluar sedang di bagian atas dipasang 
kayu untuk menutup celah tersebut. Bubu dipasang tertidur di dalam perairan dan bagian atasnya dipasang patok. Ikan yang tertangkap oleh bubu biasanya masih hidup dan untuk mengambil ikan maka bubu diangkat dari air kemudian dibalikkan. Setiap nelayan biasa memiliki lebih dari 10 buah bubu dengan harga beli Rp 25.000/buah yang bisa dipasang secara bergantian. Ikan yang biasa tertangkap bubu adalah ikan gabus dan lele.

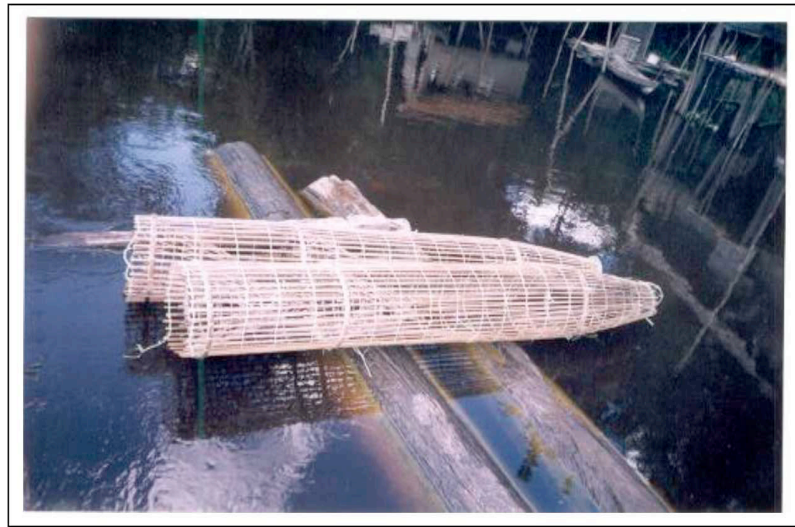

Gambar 4. Alat Tangkap Bubu.

\section{KOMPOSISI IKAN HASIL TANGKAPAN}

Komposisi alat tangkap dengan jumlah ikan hasil tangkapan di Desa Batilap, Kabupaten Barito Selatan ditampilkan pada Tabel 2. Dari keempat alat tangkap yang mayoritas digunakan oleh nelayan maka selambau merupakan alat tangkap yang menghasilkan jenis ikan yang paling banyak yaitu sebanyak 8 spesies, rengge sebanyak 6 spesies, tempirai sebanyak 5 spesies dan bubu sebanyak 3 spesies. Hal ini karena bentuk selambau yang memanjang dan merupakan jalur yang dilewati ikan sehingga ikan yang terjebak lebih banyak dari sisi jumlah dan jenis ikan. Perbedaan dari keempat mayoritas alat tangkap tersebut yaitu pada waktu penggunaan dimana rengge, tempirai dan bubu digunakan pada musim banjir sedangkan selambau digunakan pada musim kemarau. Dari hasil tangkapan yang dijelaskan terlihat bahwa komoditas utama yang dihasilkan oleh nelayan di Desa Batilap adalah ikan gabus dan biawan.

Penangkapan ikan di daerah rawa banjiran memberikan hasil yang tertinggi pada musim kemarau (Juni, Juli dan Agustus), karena saat air rendah yang biasanya berbarengan dengan musim kemarau biasanya semua jenis alat tangkap yang dioperasikan akan menangkap ikan dalam jumlah banyak (efektif) sehingga hasil tangkapan pada saat itu tinggi (Prasetyo, 2006). Hasil tangkap minimal pada saat musim hujan (Desember, Januari, Februari). Penangkapan ikan di rawa banjiran dipengaruhi oleh ketinggian air. Waktu penangkapan ikan dapat dibagi menjadi 4 periode (Welcomme 1983), yaitu :

1. Periode peningkatan tinggi air. Pada periode ini terjadi migrasi ikan dari sungai utama ke rawa lebak. Penangkapan dilakukan dengan menghadang ikan

Tabel 1. Komposisi Alat Tangkap dan Ikan Hasil Tangkapan di Desa Batilap, Kec. Dusun Hilir, Kabupaten Barito Selatan, Kalimantan Tengah Tahun 2012.

\begin{tabular}{ll}
\hline \multicolumn{1}{c}{ Jenis Alat Tangkap } & \multicolumn{1}{c}{ Jenis ikan yang tertangkap } \\
\hline Selambau (Seine net) & Haruan (Channa striatus) \\
& Kakapar (Belontia hasselti) \\
& Papuyuh (Anabas testudneus) \\
& Sepat Siam (Trichogaster pectoralis) \\
& Gabus (Channa striatus) \\
& Lele (Clarias batrachus) \\
& Biawan (Helostoma temmincki) \\
& Tauman (Ophiocephalus micropeltes CV) \\
\hline Rengge (Gill net) & Lais (Cryptopterus spp) \\
& Baung (Macrones nemurus) \\
& Tapa (Wallago lerii) \\
& Haruan (Channa striatus) \\
& Biawan (Helostoma temmincki) \\
& Kakapar (Belontia hasselti) \\
\hline Tempirai (Fish Trap) & Biawan (Helostoma temmincki) \\
& Kakapar (Belontia hasselti) \\
& Papuyuh (Anabas testudneus) \\
& Sepat Siam (Trichogaster pectoralis) \\
& Haruan (Channa striatus) \\
\hline Bubu (Portable Trap) & Gabus (Channa striatus) \\
& Biawan (Helostoma temmincki) \\
& Lele (Clarias batrachus) \\
\hline & \\
& \\
&
\end{tabular}


yang sedang bermigrasi.

2. Periode air tinggi. Pada periode ini ikan sangat tersebar di perairan rawa lebak yang luas, sehingga penangkapan memberikan hasil yang minimal.

3. Periode penurunan air. Pada periode ini tangkapan ikan terutama ikan-ikan muda yang bermigrasi dari rawa lebak menuju sungai utama.

4. Periode air dangkal. Periode ini merupakan periode yang paling produktif. Hasil tangkapan tertinggi pada periode ini. Ikan terkonsentrasi pada rawa lebak yang sudah surut airnya. Alat tangkap yang banyak digunakan adalah jaring insang, serok, trawl kecil, dan pancing.

Keadaan yang sama juga terjadi pada perairan Sungai Barito dan sungai-sungai sekitarnya dimana hasil ikan melimpah pada musim kemarau. Oleh karena itu biasanya para nelayan menggunakan selambau pada musim kemarau karena mampu menangkap dan menampung ikan dalam jumlah yang banyak.

\section{Perbandingan Komposisi Ikan Hasil Tangkapan}

Penangkapan ikan di rawa banjiran pada dasarnya menggunakan alat tangkap yang sama di setiap lokasi. Hal ini terlihat pada hasil tangkapan pada suaka perikanan Sungai Sambujur yang memiliki tipe ekosistem sama karena juga merupakan daerah aliran Sungai Barito bagian tengah. Namun, untuk setiap alat tangkap tidak memberikan hasil yang sama di masing-masing daerah. Seperti dijelaskan dalam Tabel 2.

Berdasarkan perbandingan jumlah ikan hasil tangkapan di dua lokasi tersebut di atas didapatkan hasil bahwa alat-alat tangkap di Desa Batilap lebih selektif dalam menangkap jumlah dan jenis ikan yang ada. Seperti dari bubu/lukah jenis ikan yang tertangkap di Desa Batilap lebih sedikit daripada yang tertangkap di Sungai Sambujur, Kabupaten Hulu Sungai Utara, dan juga jenis alat tangkap lainnya. Salah satu faktor

Tabel 3. Perbandingan Ikan Hasil Tangkapan di Dua Lokasi Daerah Aliran Sungai Barito Tahun 2012.

\begin{tabular}{|c|c|c|}
\hline Jenis Alat Tangkap & $\begin{array}{l}\text { Jenis Ikan yang Tertangkap di Desa } \\
\text { Batilap }\end{array}$ & $\begin{array}{l}\text { Jenis Ikan yang Tertangkap di } \\
\text { Sungai Sambujur }\end{array}$ \\
\hline Selambau (Seine Net) & $\begin{array}{l}\text { Haruan (Channa striatus) } \\
\text { Kakapar (Belontia hasselti) } \\
\text { Papuyuh (Anabas testudneus) } \\
\text { Sepat Siam (Trichogaster pectoralis) } \\
\text { Gabus (Channa striatus) } \\
\text { Lele (Clarias batrachus) } \\
\text { Biawan (Helostoma temmincki) } \\
\text { Tauman (Ophiocephalus micropeltes CV) }\end{array}$ & $\begin{array}{l}\text { Haruan (Channa striatus) } \\
\text { Kakapar (Belontia hasselti) } \\
\text { Papuyuh (Anabas testudneus) } \\
\text { Sepat Siam (Trichogaster } \\
\text { pectoralis) } \\
\text { Gabus (Channa striatus) } \\
\text { Lele (Clarias batrachus) }\end{array}$ \\
\hline Rengge (Gill Net) & $\begin{array}{l}\text { Lais (Cryptopterus spp) } \\
\text { Baung (Macrones nemurus) } \\
\text { Tapa (Wallago lerii) } \\
\text { Haruan (Channa striatus) } \\
\text { Biawan (Helostoma temmincki) } \\
\text { Kakapar (Belontia hasselti) }\end{array}$ & $\begin{array}{l}\text { Karandang (Channa } \\
\text { pleroptalmus) } \\
\text { Sepat Siam (Trichogaster } \\
\text { pectoralis) } \\
\text { Seluang (Rasbora sp) } \\
\text { Tapa (Wallago lerii) } \\
\text { Haruan (Channa striatus) } \\
\text { Biawan (Helostoma temmincki) } \\
\text { Kakapar (Belontia hasselti) }\end{array}$ \\
\hline Tempirai (Fish Trap) & $\begin{array}{l}\text { Biawan (Helostoma temmincki) } \\
\text { Kakapar (Belontia hasselti) } \\
\text { Papuyuh (Anabas testudneus) } \\
\text { Sepat Siam (Trichogaster pectoralis) } \\
\text { Haruan (Channa striatus) }\end{array}$ & $\begin{array}{l}\text { Biawan (Helostoma temmincki) } \\
\text { Kakapar (Belontia hasselti) } \\
\text { Karandang (Channa } \\
\text { pleroptalmus) } \\
\text { Papuyuh (Anabas testudneus) } \\
\text { Sepat Siam (Trichogaster } \\
\text { pectoralis) } \\
\text { Seluang (Rasbora sp) }\end{array}$ \\
\hline Bubu (Portable Trap) & $\begin{array}{l}\text { Gabus (Channa striatus) } \\
\text { Biawan (Helostoma temmincki) } \\
\text { Lele (Clarias batrachus) }\end{array}$ & $\begin{array}{l}\text { Biawan (Helostoma temmincki) } \\
\text { Kakapar (Belontia hasselti) } \\
\text { Sepat siam (Trichogaster } \\
\text { pectoralis) } \\
\text { Seluang (Rasbora sp) } \\
\text { Papuyuh (Anabas testudneus) }\end{array}$ \\
\hline
\end{tabular}


terjadinya perbedaan ikan hasil tangkapan dari penggunaan mata jaring yang digunakan oleh nelayan Desa Batilap lebih besar dan mengikuti peraturan pemerintah minimal $2,5 \mathrm{~cm}$.

\section{KESIMPULAN}

Desa Batilap di Kecamatan Dusun Hilir sebagai salah satu desa nelayan di Kabupaten Barito Selatan dimana hampir $100 \%$ penduduknya berprofesi sebagai nelayan yang menggunakan berbagai macam alat tangkap dalam pekerjaannya. Dari berbagai macam alat tangkap terdapat 4 mayoritas alat tangkap yang dimiliki dan digunakan oleh para nelayan yaitu selambau, rengge, tempirai dan bubu dengan waktu penggunaan yang berbeda-beda. Selambau biasa dipasang pada musim kemarau sedangkan yang lainnya pada musim banjir. Ikan yang didapat dari tiap alat tangkap juga berbedabeda dari jenis dan jumlahnya. Ikan yang tertangkap selambau sebanyak 8 jenis, rengge sebanyak 6 jenis, tempirai sebanyak 5 jenis dan bubu 3 jenis. Musim penangkapan ikan terjadi sepanjang tahun namun ikan melimpah pada musim kemarau yaitu (Juni,Juli dan Agustus) sedangkan hasil minimal diperoleh pada musim penghujan (Desember, Januari dan Februari). Meskipun dengan keadaan cuaca saat ini yang tidak menentu namun ikan-ikan masih banyak bisa dihasilkan oleh para nelayan di Desa Batilap tersebut. Di setiap rawa banjiran menggunakan alat tangkap yang sama jenisnya namun berbeda-beda jumlah dan jenis ikan yang tertangkap. Hal ini salah satunya dikarenakan penggunaan mata jaring yang berbeda ukuran di setiap alat tangkap.

\section{DAFTAR PUSTAKA}

Badan Pusat Statistik Kabupaten Barito Selatan. 2012. Barito Selatan dalam Angka. Badan Pusat Statistik Kabupaten Barito Selatan. Barito Selatan.

Cahyono,B. 2001. Budidaya Ikan di Perairan Umum. Penerbit Kanisius. Yogyakarta.

Dinas Perikanan dan Peternakan Kabupaten Barito Selatan. 2012. Masterplan Minapolitan Barito Selatan. Dinas Perikanan dan Peternakan Kabupaten Barito Selatan. Barito Selatan.
Dinas Kelautan dan Perikanan Provinsi Kalimantan Tengah. 2010. Profil Perikanan Tangkap di Perairan Umum Provinsi Kalimantan Tengah. Dinas Kelautan dan Perikanan Provinsi Kalimantan Tengah. Palangkaraya.

Ondara. 1992. Pemanfaatan dan Pengelolaan Perikanan Perairan Umum. Temu Karya IImiah Perikanan Perairan Umum, Palembang 12-13 Februari 1992. Pusat Penelitian dan Pengembangan Perikanan. Badan Penelitian dan Pengembangan Pertanian. Departemen Pertanian

Prasetyo, D. dan Asyari. 2003. Inventarisasi Jenis Ikan dan Karakteristik Sungai Barito. Sosialisasi Hasil Penelitian Tahun 2002. Prosiding Pusat Riset Perikanan Tangkap. Puris Tangkap. Badan Riset Kelautan dan Perikanan. Departemen Kelautan dan Perikanan. Jakarta. 37-42

Prasetyo, D.2006. Kegiatan Penangkapan Ikan di Suaka Perikanan Sungai Sambujur Daerah Aliran Sungai Barito Bagian Tengah, Kalimantan Selatan. Jurnal Perikanan Vol 8 No 2. Fakultas Perikanan Universitas Gajah Mada. Yogyakarta: 239-246.

Prasetyo,D.2006. Kegiatan Penangkapan Ikan di Suaka Perikanan Danau Panggang Kabupaten Hulu Sungai Utara, Kalimantan Selatan. Prosiding Seminar Nasional Forum Perairan Umum Indonesia III. Balai Riset Perikanan Perairan Umum. Palembang. 203-210

Utomo,A.D.1996. Ekologi Sungai Musi. Kumpulan Makalah Seminar Penyusunan Pengelolaan dan Evaluasi Hasil Penelitian Perikanan Perairan Umum. Sub Balitkanwar, Puslitbangkan, Badan Litbang, Deptan. Palembang. 27-28 Februari 1996 : 55-62.

Welcomme,R.L. 1985. River Fishery.FAO.Fish.Tech.Paper (262).Rome.330p 